Lidia Sierpińska

\title{
HEPATITIS C AS AN EPIDEMIOLOGICAL PROBLEM IN THE POLISH POPULATION
}

\author{
WIRUSOWE ZAPALENIE WĄTROBY TYPU C \\ JAKO PROBLEM EPIDEMIOLOGICZNY W POLSKIEJ POPULACJI
}

Military Clinical Hospital No. 1 with Polyclinic, Independent Public Health Unit, Lublin

S u m m a r y

Introduction. Hepatitis $\mathrm{C}(\mathrm{HC})$ is an important medical and social problem in Poland and worldwide. The etiologic factor of the disease is the hepatitis $\mathrm{C}$ virus (HCV), which is transmitted by blood and blood preparation.

Objective. Epidemiological analysis of the prevalence of hepatitis $\mathrm{C}$ in the Polish population, based on preliminary results of scientific studies and statistical data.

R e sults. The estimation data show that in Poland the number of new cases increases annually by approximately 3000 patients. The HCV is characterized by a high level of genetic changeability, which contributes to the limited therapeutic possibilities and renders the development of a vaccine impossible. Since 1997 in Poland, the number of deaths due to HCV infection has been increasing, and in the nearest years it will increase several times. In Poland, hepatitis $\mathrm{C}$ is frequently noted among hospital-acquired infections. These infections are one of the most frequent sources of legal proceedings by patients and their families.

Conclusions. Hepatitis C (HC) is an important clinical, epidemiological, economic and social problem in Poland and worldwide. HCV is characterized by a high degree of variation, which contributes to the limited therapeutic possibilities and makes it impossible to develop a vaccine. Infections with $\mathrm{HCV}$ are a frequent cause for bringing civil cases to court by previous patients against health care facilities for compensations for health loss related with infection acquired during diagnosing and treatment. Considering the high risk of infection with $\mathrm{HCV}$ virus in health facilities non-specific diagnostics should be carried out within wide range.

\section{Streszczenie}

W p r ow a d z e n i e. Wirusowe zapalenie wątroby typu C (WZW typu C) stanowi istotny problem medyczny i społeczny w Polsce i na świecie. Czynnikiem etiologicznym tej choroby jest wirus HCV (ang. hepatitis $C$ virus), który jest przenoszony za pośrednictwem krwi i preparatów krwiopochodnych.

Ce 1 pracy. Epidemiologiczna analiza występowania WZW typu C w polskiej populacji w oparciu o dostępne wyniki badań naukowych oraz dane statystyczne.

Wyniki. Z danych szacunkowych wynika, że $\mathrm{w}$ Polsce nowych zachorowań w ciągu roku przybywa o około 3 tys. Wirus HCV cechuje się wysokim stopniem zmienności genetycznej, co przyczynia się do ograniczonych możliwości terapeutycznych oraz uniemożliwia opracowanie szczepionki. Liczba zgonów w Polsce spowodowanych
WZW typu C od 1997 roku wzrasta i w najbliższych latach zwiększy się kilkakrotnie. W Polsce WZW typu C jest istotnie często odnotowywane wśród zakażeń szpitalnych. Zakażenia te są jednym z najczęstszych źródeł roszczeń pacjentów i ich rodzin.

$\mathrm{W}$ n i o s k i. Wirusowe zapalenie wątroby typu C ( HCV - hepatitis C virus) stanowi istotny problem kliniczny, epidemiologiczny, ekonomiczny i społeczny w kraju i na świecie. Wirus HCV charakteryzuje się wysokim stopniem zmienności, co przyczynia się do ograniczonych możliwości terapeutycznych oraz uniemożliwia opracowanie szczepionki. Zakażenia wirusem HCV są częstą przyczyną spraw cywilnych wnoszonych przez byłych pacjentów przeciwko podmiotom leczniczym o odszkodowanie za uszczerbek na zdrowiu, związany $\mathrm{z}$ zakażeniem nabytym podczas 
diagnozowania lub leczenia. Wobec wysokiego ryzyka zakażenia wirusem HCV w podmiotach leczniczych należy prowadzić w szerokim zakresie profilaktykę nieswoistą.

Key words: hepatitis C, epidemiological data, Polish population, hospital-acquired infection

Stowa kluczowe: nietrzymanie moczu, fizjoterapia urologiczna, terapia dna miednicy, geriatria

\section{INTRODUCTION}

A several-year evaluation of the epidemiological situation in Poland shows that hepatitis is a serious clinical, diagnostic, epidemiological, economic and social problem in the populations of adults and children. Estimation data show that in 2005 in Poland, about 600000 people were infected with $\mathrm{HCV}$, whereas in 2013, as many as approximately 730 000. It is estimated that in Poland patients infected with the hepatitis $\mathrm{C}$ virus constitute about $2 \%$ of the total population, and at least $50 \%$ of those infected are unaware of the ongoing pathological process. Frequently, the disease takes an asymptomatic or poorly symptomatic course, and the diagnosis is made coincidentally.

The etiologic factor of hepatitis $\mathrm{C}$ is the hepatitis $\mathrm{C}$ virus. The incubation period of $\mathrm{HCV}$ is 45 days, on average. The only reservoir of the $\mathrm{HCV}$ virus and the source of infection are humans. The $\mathrm{HCV}$ is transmitted by blood, and proliferates (replicates) mainly liver cells (hepatocytes), as well as in other organs, i.e. spleen, pancreas, adrenals, brain, bone marrow, thyroid gland, lymph nodes, peripheral blood mononuclear cells (lymphocytes, monocytes, macrophages) [1].

A break in the continuity of tissues is among the routes of $\mathrm{HCV}$ virus infections. Such hazards are: blood transfusion and other contacts with blood; while performing a tattoo, acupuncture, procedures at a hairdresser; with relation to the use of narcotics by the intravenous route; during childbirth; in relation to dialysotherapy, transplantation of organs from an infected donor; by medical equipment (e.g. gastroscope) infected with $\mathrm{HCV}$; and by sexual contact with an infected partner [2-3].

\section{OBJECTIVE}

Epidemiological analysis of the prevalence of hepatitis $\mathrm{C}$ in the Polish population, based on preliminary results of scientific studies and statistical data.

\section{RESULTS}

The hepatitis $\mathrm{C}$ virus (HCV) was first isolated by Q.L. Hao et al. in 1989, through genetic methods [4]. The period of incubation of HCV virus is 14-180 days (45 days, on average). HCV virus is resistant to high temperature, it dies only during the process of sterilization at a temperature of over $140^{\circ} \mathrm{C}$. It can survive outside the organism for up to three weeks. It is sensitive to chlorine-based disinfectants and to ethanol. $\mathrm{HC}$ virus has a spherical structure with a particle diameter of approximately 50 nanometers. It is covered with a coat of lipoproteids, i.e. normal components of blood serum. Lipoproteids protect the virus against attack by antibodies, facilitate its penetration into the cells, and serve as a kind of carrier. Hepatic cells have receptors on their surface designed for capturing lipoproteins. The HCV is single-stranded RNA virus, twice as large as the HBV virus. The particles of the virus have various buoyant density in saccharose [5].

In Poland, it was not until 1992 that blood from donors began to be examined for the presence of $\mathrm{HCV}$ during screening tests, and the determination of antiHCV antibodies was started. Subsequently, since 2000, tests for RNA HCV began to be performed. From that time, due to the tests, the risk of infection by the route of blood transfusion decreased considerably - to a minimum [6]. The HCV virus is an RNA virus belonging to the family Flaviviridae, genus Hepacivirus, and shows affinity to hepatocytes and blood mononuclear cells. The presence of an agent other than the viruses known until then: hepatitis $A$ virus (HAV) and hepatitis B virus (HBV) was suspected much earlier. Its presence was indicated by both clinical observations and experiments on animals [7]. At that time, the commonly used terms were non-A and non-B hepatitis. During subsequent years, diagnostic tests for the presence of infection were implemented and improved. It was found that $\mathrm{HCV}$ has tremendous mutation capabilities and occurs in 6 various genotypes, each of them divided into subtypes (50 subtypes). The major difference between these subtypes and genotypes is the response to treatment. Genotypes 1, 2 and 3 occur worldwide; however, genotype 3 a dominates, which is the cause of hepatitis 
in $50 \%$ patients with HCV globally. Genotypes 4 and 5 more frequently occur in Africa, while genotype 6 in Asia. Unfortunately, in Poland, genotype 1 subtype $b$ is prevalent (70\% of infections), which most poorly responds to treatment with interferon [8]. Estimated data show that the effectiveness of treatment in type $1 \mathrm{~b}$ is approximately $56-57 \%$ of the total number of patients.

Based on the relevant literature, worldwide there live approximately 170 million people infected with hepatitis $\mathrm{C}$ virus, which constitutes $3 \%$ of the total population [9]. Each year, a subsequent 3-4 million people in the world become infected with this virus. In the light of the above-mentioned facts, hepatitis $\mathrm{C}$ has been considered by the World Health Organization as one of the greatest epidemiological risks. The largest number of infected population is observed in certain regions of Africa, Asia, and South America (10\%), and in Egypt (14.5\%). In the United States the number of people infected with $\mathrm{HCV}$ is determined to be 3.2 million (1.3\% of the population) $[10,11]$. On the European continent, the greatest prevalence of the virus is noted in Eastern Europe - from 1.5\% - 5.0\% [12]. Analysis of morbidity due to hepatitis $\mathrm{C}$ in all European countries during the period 1995-2005 shows that this infection was most rare in Scandinavian countries and in Holland (frequency of infection $<0.5 \%$ ). In the remaining countries of Europe, the frequency of infections during this period exceeded $0.5 \%$, and in Romania and the Ukraine was more than $3.6 \%$ of the total population. Poland was in the groups of countries where the frequency of infections remained within the range from $1.6 \%-2.5 \%$ [13].

In Poland, hepatitis $\mathrm{C}$, as a distinct disease unit, started to be registered by the National Department for Hygiene (PZH) since 1997. Officially, about 800-3 000 cases of infection were noted annually. The epidemiological data published are incomplete. It is estimated that at least $50 \%$ of infected individuals remain unaware of the ongoing pathological process. It was found that since 1997 a half of Poles infected with $\mathrm{HCV}$ and registered by the $\mathrm{PZH}$, were subjected to screening tests by a blood station. In 1998, 1,561 cases of hepatitis $\mathrm{C}$ were noted in the entire country (incidence 4.04/100 000 inhabitants) [14]. In 1999, the incidence rate was 2.58/100 000 inhabitants, whereas after 5 years it increased up to 5.4/100 000 inhabitants (2004)

Considering very alarming epidemiological data with respect to infections with $\mathrm{HCV}$, in 2004 in
Poland, on the initiative of the Main Councils of the Polish Society of Epidemiologists and Infectious Diseases Physicians, and the Polish Society for Hepatology, the Polish Group of HCV Experts was created. On the initiative of this Group, the Project of a National Programme for the Control of $\mathrm{HCV}$ Infections was developed in 2005. Within this Project, since 2006, all cases with positive anti-HCV antibodies began to be registered, and not, as previously, exclusively the symptomatic cases. The abovementioned change in the registration of patients infected with HCV made real the epidemiological data in Poland [15].

In 2005 , the incidence rate was $7.9 / 100000$, and the cases of infection concerned mainly adults. Epidemiological data show that in 2009, similar to previous years, the incidence of hepatitis $\mathrm{C}$ was twice as high in urban than rural areas $(6.61 \%$ and $3.23 \%$, respectively), and was also higher among males than females $(6.09 \%$ and $4.55 \%$, respectively). The highest incidence and prevalence was observed among males and females in the age group 50-54, and an increase in incidence (19\%) among adults was observed among those aged 35-54, also, to a greater extent it concerned males rather than females ( $28 \%$ and $9 \%$, respectively). It was also found that until 2009, the largest number of cases were noted in the Regions of: Kielce, Łódź, Poznań, and Olsztyn [16].

Analysis of data for 2011 concerning the population infected with the hepatitis $\mathrm{C}$ virus, compared to previous years, demonstrated that from 2009, the incidence of hepatitis C showed an upward tendency (based on registered cases). In 2009 in Poland, 1939 new cases were noted (incidence 5.08/100 000 inhabitants). According to researchers, the increase in the incidence observed may be the consequence of a better availability of examinations during that period [17]. In 2010 in Poland, 2021 cases of hepatitis C were registered (incidence 5.29/100 000 inhabitants) [18].

In 2011, as many as approximately 730000 of Polish inhabitants were infected $(1.9 \%$ of the total population) [19]. Based on studies carried out in Poland, it was confirmed that $30-40 \%$ of those infected were carriers of the HCV virus, which means that 220300000 Poles may infect others. The studies conducted by the Centre for Public Opinion Research TNS OBOP, by order of Roche Poland, in 2007 showed that more than $60 \%$ of Poles had heard about hepatitis C, and 54\% were aware that this is an 
infectious disease. As many as $45 \%$ of respondents incorrectly reported that there is a vaccine against $\mathrm{HCV}$ virus. About $1 / 3$ of respondents considered that it is necessary to isolate patients with hepatitis $\mathrm{C}$, while only $9 \%$ recognized the term $\mathrm{HCV}$ defining the hepatitis $\mathrm{C}$ virus; these were mainly well educated individuals from large cities, possessing a good material standard. When the name of the disease was quoted in a wider scope: hepatic $\mathrm{C}$ virus and jaundice type $\mathrm{C}$ - the percentage of correct answers was $63 \%$. During the studies, the respondents who identified hepatitis $\mathrm{C}$ as an infectious disease were asked about the source of infection. The largest number of Poles $(60 \%)$ reported that the source of infection with the $\mathrm{HCV}$ virus are infected medical instruments and contact with blood (56\%). It was observed, that respondents who knew that hepatitis $\mathrm{C}$ is an infectious disease mentioned places where there is a very high risk of infection with the HCV virus. These were places connected with medical care: hospitals, facilities where medical examinations and procedures are performed, dental surgeries, and blood collection sites [20].

In approximately $15 \%$ of people infected with $\mathrm{HCV}$, acute symptoms of infection are observed (asthenia, flu-like complaints, abdominal pain, yellowish discoloration of the skin, very high values of liver enzymes in blood). Forms taking a fulminant course occur rarely. The disease often has an asymptomatic or poorly symptomatic course, and the diagnosis is made by coincidence. In some patients infected with $\mathrm{HCV}$, there may occur a phase of warning symptoms, which disappear after the occurrence of jaundice (jaundice is the feature of an acute phase). Apart from this, in many patients an enlargement of the liver is diagnosed. Noncharacteristic symptoms cover: reduced appetite, nausea, and loss of body weight. This period may cause diagnostic difficulties. In nearly $1 / 4$ of infected patients, spontaneous viral clearance is observed, without treatment, within the first several months of the disease [21]. In chronic hepatitis, in the majority of patients there develops at least one of the non-hepatic symptoms, such as weakness, lowered mood, muscles and joints pain, itchy skin, parestheses, dryness of mucous membranes and symptoms resembling Raynaud's phenomenon, i.e. paroxymal constriction of the arteries in the regions of hands or feet, causing temporary ischemia and fingers turning a bluish colour. Among the complications are mentioned those related with the deposition of immune complexes, i.e. glomerulonephritis, vasculitis, and erythema nodosum. In addition, chronic hepatitis $\mathrm{C}$ leads to the development of inflammatory and necrotic foci with fibrosis in the hepatic parenchyma. The progressing hepatic fibrosis may, after 20-30 years in 20-30\% of infected patients, lead to liver cirrhosis, which is a life threatening complication. This leads to hepatic failure and, in consequence, the subsequent complications develop: oesophageal varices, haemorrhoids, ascites, and hepatic encephalopathy. A dangerous complication of $\mathrm{HCV}$ infection is primary hepatocellular carcinoma.

The treatment for chronic hepatitis $\mathrm{C}$ consists in the administration of interferon alpha and drugs inhibiting replication of viruses (ribavirin). The therapeutic process depends on the $\mathrm{HCV}$ genotype. Intensive treatment may last from 6 months to one year. If the therapeutic effect is not achieved it is recommended that the treatment should be repeated; however, the chances for curing are considerably lower than at the first attempt, or none, because, unfortunately, not all patients can be successfully cured. A severe course of chronic hepatitic C may lead to death [22]. Based on the estimation data, in Poland, the number of deaths due to this cause has increased since 1997: 1997(23), 1998(34), 1999(41), 2000(52), 2001(73), 2002(91), 2003(116) 2004(124), 2007(132), 2010(167) [18, 22, 23].

The HCV virus is transmitted with blood. It is estimated that the greatest majority of cases of hepatitis $\mathrm{C}$ in Poland (approximately $80 \%$ ) are associated with medical procedures performed in medical facilities, especially by injections, collection of blood, as well as instrumental, diagnostic, treatment and surgical procedures. The infection may also occur during procedures at a beautician, manicurist, hairdresser, while tattooing or piercing of the body. A large group of patients chronically ill with hepatitis $\mathrm{C}$ are drug addicts - about $70 \%$.

Analysis of the relevant literature shows that the groups exposed to risk of $\mathrm{HCV}$ infection belong individuals who:

- had blood or blood products transfusions performed before 1992;

- hospitalized many times,

- had minor surgical procedures performed (e.g. removal of marks, tooth extraction), dialyses, endoscopic examinations;

- had a past history of hepatitis B;

- take narcotics by intravenous route; 
- use tattoo parlours, cosmetic parlours;

- with risky sexual contacts;

- using common cosmetic instruments and toothbrushes;

- health care staff [19].

Analysis of epidemiological data concerning the occurrence of selected infectious diseases in Poland during the period 2005-2012 demonstrate that hepatitis $\mathrm{C}$ was significantly more often noted among hospitalacquired infections $(2005$ - 2993; 2006 - 3025; 2007 $2811 ; 2008$ - 2391; 2009 - 2891; 2010 - 2178; 2011 2189; 2012 - 2265) [24].

based on the studies conducted during $1993-2000$ from 345 civil cases brought to court by previous patients against health care facilities for compensations for health loss related with infection acquired during diagnosing or treatment, the largest number of cases were those brought after past hepatitis $\mathrm{B}$ and $\mathrm{C}-\mathrm{a}$ total number of $330(95.7 \%)$ cases - due to infection with HCV - 91 cases (26.4\%). Hospital-acquired infection for this reason took place in the following wards: surgical (87 cases), gynaecological (34 cases), orthopaedic (39 cases), which confirms that in surgical wards there is a high risk of infection with hepatitis $\mathrm{B}$ and $\mathrm{C}$ [25].

Analysis of literature data shows that in the years 2007-2014, the percentage of claims by patients for hospital-acquired infection with HCV remained on the level of $33.0 \%$ [26].

Prevention of the spread of infections with HCV virus is possible exclusively by way of non-specific prophylaxis, the essence of which is severing the routes of infection by improving the sanitary and hygienic status, and observance of the principles of hygiene. There is a lack of specific methods for the prevention of infection, with $\mathrm{HCV}$ by, e.g. active (protective vaccinations) or passive (specific immunoglobulines) immunization [19].

\section{CONCLUSIONS}

1. Hepatitis $\mathrm{C}(\mathrm{HC})$ is an important clinical, epidemiological, economic and social problem in Poland and worldwide (approximately 730000 people infected in Poland and approximately 170 million worldwide).

2. HCV is characterized by a high degree of variation, which contributes to the limited therapeutic possibilities and makes it impossible to develop a vaccine.
3. According to the estimation data by the WHO, with the lack of an appropriate therapy the number of deaths due to HCV infection will increase several times in the next few years.

4. Infections with $\mathrm{HCV}$ are a frequent cause for bringing civil cases to court by previous patients against health care facilities for compensations for health loss related with infection acquired during diagnosing and treatment.

5. Considering the high risk of infection with $\mathrm{HCV}$ virus in health facilities non-specific diagnostics should be carried out within wide range.

\section{REFERENCES}

1. Kamińska A., Bednarska A., Radkowski M.: Extrahepatic replication of $\mathrm{HCV}$ virus. Przegl Epidemiol 2003; 57, 317-322.

2. Alter M.J.: Prevention of spread of hepatitis C. Hepatology 2002 (Suppl. 1); 36, 93-98.

3. Maasoumy B., Wedemeyer H.: Natural history of acute and chronic hepatitis C. Best Pract Res Clin Gastroenetrol 2012; 26(4), 401-412.

4. Choo Q.L., Kuo G., Weiner A.J., et al.: Isolation of a DNA clone derived from a blood-borne non-A, non-B viral hepatitis genome. Science 1989; 244(4902), 359-362.

5. Felmleem D.J., Hafirassou M.L., Lefevre M. et al.: Hepatitis $\mathrm{C}$ virus, cholesterol and lipoproteins-impact factor the viral life cycle and pathogenesis of liver disease. Viruses 2013; 5(5), 1292-1324.

6. Tyczewska A., Bąkowska-Żywicka K.: Attenuation of miR-122 - new therapy of hepatitis C? Biotechnologia 2010; 3(90), 29-35.

7. Halota W., Pawłowska M.: Hepatotropic virus infection. Med Sci Rev Hepatologia 2001; 1, 43-57.

8. Halota W., Pawłowska M., Bulik F., et al.: Serotypes of HCV in Polish population. Hepatologia Polska 1998; 5(1), 3-7.

9. Fabrizi F., Messa P., Martin P.: The unravelled link between chronic kidney disease and hepatitis C infection. New Journal of Science 2014; Article ID, 1-9.

10. World Health Report. World Health Organization. Geneva 2002.

11. Armstrong G.L., Wasley A., Smard E.P., et al.: The prevalence of hepatitis $C$ virus infection in United States, 1999 through 2002. Ann Intern Med 2006; 144, 705-714.

12. Lavanchy D.: Evolving epidemiology of hepatitis $C$ virus. Clinical Microbiology and Infection 2011; 17(2), 107-115.

13. Habior A.: Liver disease a threat to Europe in the $21^{\text {st }}$ century. Postępy Nauk Medycznych 2009; 2, 77-83.

14. Mazurek J.: Importance of definition of a case of disease in epidemiological surveillance on example of 
assessment of the number of hepatitis $\mathrm{C}$ cases. Przegl Epidemiol 2001; 55, 183-188.

15. Muszyńska A., Pokorna-Kałwak D., Steciwko A.: HCV infections - a growing p[ublic health problem. Terapia 2010; 5(2), 55-58.

16. Rosińska M., Stępień M.: Hepatitis C in Poland in 2009. Przegl Epidemiol 2011; 65, 265-269.

17. Rosińska M., Parda N., Stępień M.: Hepatitis C in Poland in 2011. Przegl Epidemiol 2013; 67, 353-356.

18. Rosińska M., Radziszewski F., Stępień M.: Hepatitis C in Poland in 2010. Przegl Epidemiol 2012; 66, 287-292.

19. Flisiak R., Halota W., Horban A., et al.: Prevalence and risk factors of $\mathrm{HCV}$ infection in Poland. $\mathrm{Eu} \mathrm{J}$ Gastroenterol Hepatol 2011; 23(12), 1213-1217.

20. TNS OBOP. Knowledge concerning hepatitis. Report from 2011 study.

21. Stępień M., Rosińska M.: Studies of prevalence of HCV in Poland - where are we? Przegl Epidemiol 2011; 65, 15-20.

22. Magdzik W.: Hepatitis C. Most important epidemiological aspects. Przegl Epidemiol 2006; 60, 751-757.
23. Laskus I., Rosińska M.: Hepatitis C in Poland in 2007. Przegl Epidemiol 2009; 63, 251-254.

24. Main Sanitary Inspectorate. Sanitary state in Poland in 2012. Warszawa 2013.

25. Chowaniec Cz., Chowaniec M.: Problems with providing opinions in case of hospital-acquired infections, especially with hepatitis $\mathrm{B}$ and $\mathrm{C}$ viruses. Arch Med Sąd i Krym 2001; 51(1), 11-20.

26. Pałka J., Truszkiewicz W.: Hospital-acquired infections as the cause of making civil claims by patients. Arch Med Sąd Krym 2007; 57(1), 81-84.

\section{Address for corroespondence:}

Lidia Sierpińska

Military Clinical Hospital No. 1 with Polyclinic, Independent Public Health Unit,

Al. Racławickie 23, 20-049 Lublin

Tel. +48 (81 2611832 97; 507810339

Fax: +48981) 261183277 ;

e-mail: sierpinska1@wp.pl

Received: 16.03.2015

Accepted for publication: 8.06.2015 